\title{
STUDI ALTERASI DAN MINERALISASI DISEKITAR GUNUNG AGUNG, KABUPATEN KULONPROGO - PURWOREJO
}

\author{
Oleh: \\ Chusni Ansori dan Defry Hastria \\ Balai Informasi dan Konservasi Kebumian Karangsambung LIPI-Kebumen \\ Jalan Karangsambung KM.19, Kebumen
}

\section{SARI}

Daerah Gunung Agung secara administratif termasuk dalam wilayah Kecamatan Kokap, Kabupaten Kulonprogo, Provinsi Daerah Istimewa Yogyakarta dan Kecamatan Bagelen, Kabupaten Purworejo, Provinsi Jawa Tengah. Secara regional termasuk dalam Pegunungan Kulonprogo yang di daerah ini dijumpai indikasi alterasi dan mineralisasi logam.

Pengamatan lapangan dan pemercontohan diikuti dengan analisis petrografi, X-RD, kimia mineral dan inklusi fluida. Studi dilakukan untuk mengetahui proses dan posisi mineralisasi.

Mineralisasi yang berkembang umumnya berupa urat dan stock work silika-kuarsa yang diikuti pembentukan mineral ubahan lempung argilik disekitarnya, dengan intensitas lemah-sedang. Urat silika-kuarsa mempunyai ketebalan 10-30 cm, dengan kadar Au berkisar 50-2.608 ppb. Hasil analisis XRD dan petrografi dijumpai adanya asosiasi mineral kuarsa, pirit, barit, muskovit dan serisit. Hasil pengamatan dengan metoda inklusi fluida pada urat kuarsa menunjukan fasa tunggal dan ganda, umumnya mengalami necking dengan kandungan $\mathrm{NaCl}$ : 2,5 - 3,9 \% berat, suhu homogenisasi antara $157^{\circ} \mathrm{C}$ hingga $225^{\circ} \mathrm{C}$.

Proses alterasi terjadi dalam dua tahap, tahap pertama terjadi alterasi mesotermal pada suhu antara $280-340^{\circ} \mathrm{C}$, sehingga mengubah mineral feldspar menjadi serisit dan asosiasi mineral sulfida. Tahap kedua, terjadi proses alterasi epitermal pada crustiform-colloform hingga kalsedonik superzone, suhu $175-230^{\circ} \mathrm{C}$, yang menghasilkan asosiasi mineral barit, sulfida dan logam mulia.

Kata kunci : Alterasi, Gunung Agung, Mineralisasi

\section{ABSTRACT}

Mount Agung region at Kokap district - Kulonprogo and Bagelen district - Purworejo is included in the Kulonprogo Dome, where indications of alteration and metal mineralization are found. This study aimed to determine the position and process of alteration, mineralization. Fieldwork and sampling were carried out as well as petrographic, $X-R D$, mineral chemistry and fluid inclusion analyses.

General alteration in the study area evolve of veins and stock work of silica-quartz which is followed by the argillic

clays, with weak-moderate intensity. Alteration and mineralization zones were found around Mount Agung at Kalirejo village, Kokap - Kulonprogo, and Sumorejo village at Bagelen district Purworejo. Silica-quartz veins have thickness of 10-30 cm, sparse density, with detected ranged of Au 50-2608 ppb. From XRD and petrographic analyses we found an association of quartz, pyrite, barite, muscovite and sericite minerals. Fluid Inclusion has single and double phase, which generally experience necking with $\mathrm{NaCl}$ content: 2.5 to $3.9 \%$ by weight, the homogenization temperature between $157^{\circ} \mathrm{C}$ and $225^{\circ} \mathrm{C}$.

The process of alteration occurs in 2 stages, the first stage of mesotermal alteration occurs at high temperatures between $280-340^{\circ} \mathrm{C}$, at crystalline superzone over $500 \mathrm{~m}$ depths, wich transform the feldspar into sericite and sulphide mineral association. The second stage, a process of epithermal alteration at crustiform-colloform to calsedonic superzone, at $175-230^{\circ} \mathrm{C}$ temperture, shallow depths (100-160 m), which produces associations of barite, sulphides and precious metals.

Keyword: Alteration, Agung Mountain, Mineralisation 


\section{PENDAHULUAN}

\section{Latar belakang}

Morfologi Pegunungan Serayu Selatan Bagian Timur dikontrol oleh struktur antiklin yang memanjang ke arah timur membentuk antiklinorium Karangsambung dan morfologi kubah mulai dari Purworejo menerus hingga lembah Sungai Progo yang dikenal sebagai Pegunungan Kulon Progo (Asikin dkk., 1992). Indikasi keberadaan aktivitas vulkanisme di Kulon Progo dapat diamati dari citra satelit maupun peta topografi. Aktivitas vulkanisme tersebut menghasilkan batuan vulkanik di Kulon Progo yang berkembang pada jalur busur magmatik Sunda - Banda selama Oligosen - Miosen (Soeria Atmaja dkk., 1994). Keberadaan beberapa gunung api purba menyerupai gumuk serta intrusi Gunung Agung berpengaruh terhadap proses alterasi-mineralisasi.

Penelitian ini bertujuan untuk mengetahui kemungkinan terbentuknya alterasi dan mineralisasi yang berkembang di sekitar tubuh intrusi Gunung Agung sebagai indikasi terjadinya proses hidrotermal serta suhu dan posisi mineralisasinya.

\section{Metode penelitian:}

- Penelitian lapangan, dilakukan melalui pengamatan litologi dan struktur geologi serta mencari zone alterasi dan mineralisasi.

- Penelitian laboratorium; meliputi analisis petrografi menggunakan mikroskop polarisasi nikon di LIPI - Karangsambung, X-RD di Laboartorium Fisika Mineral Pusat Penelitian dan Pengembangan Teknologi Mineral dan Batubara (TekMIRA), kimia mineral di Laboratorium Kimia Mineral Pusat Sumber Daya Geologi (PSDG) dan inklusi fluida di Laboratorium Optik Pusat Penelitian Geoteknologi LIPI.

\section{Geologi}

Pegunungan Kulon Progo merupakan bagian dari Kompleks Pegunungan Serayu Selatan yang terletak diujung bagian Timur (Van Bemmelen, 1949). Kompleks Pegunungan Serayu Selatan secara umum berarah Barat-Timur, sedangkan Pegunungan Kulon Progo berarah hampir
Selatan-Utara atau Baratdaya-Timurlaut yang berlainan dengan arah umum kompleks tersebut. Pegunungan Kulon Progo merupakan suatu kubah atau dome berbentuk empat persegi panjang (Van Bemmelen, 1949). Sumbu panjang kubah ( \pm $32 \mathrm{Km}$ ) berarah Selatan Baratdaya-Utara Timurlaut, sedangkan Sumbu pendek $( \pm 20$ $\mathrm{Km}$ ) berarah Barat Baratlaut-Timur Tenggara. Bagian atas kubah merupakan suatu pedataran tinggi (859 $\mathrm{m}, \mathrm{dpl}$ ) yang terkenal dengan nama plato Jonggrangan.

Secara fisiografis Pegunungan Kulon Progo termasuk ke dalam dome atau bagian tengah zona depresi yang berada di bagian timur zona Pegunungan Serayu Selatan dengan arah yang agak berbeda mengarah Baratdaya-Timurlaut dari arah umum Barat-Timur. Bentuk wilayah ini akibat proses periode tektonik yang berbeda dengan melibatkan formasi-formasi batuan yang berlainan, dan tektonik aktif yang terlihat dari pola deformasinya (Budiadi, 2008).

Menurut Rahardjo dkk (1977), endapan paling tua adalah Formasi Nanggulan yang berumur Eosen - Oligosen dan tersusun oleh napal, batu pasir, batu lempung sisipan lignit. $\mathrm{Di}$ atasnya diendapkan secara tidak selaras Formasi Kebo-Butak yang disebut juga Formasi Andesit Tua. Formasi ini tersusun oleh breksi andesit, tufa, lapilli, aglomerat, lava dan intrusi andesit berumur Oligo-Miosen. Pada Miosen Akhir hingga Pliosen secara tidak selaras di atasnya diendapkan batugamping Formasi Jonggrangan yang menjemari dengan Formasi Sentolo. Endapan paling muda berumur Kuarter, dengan susunan bagian bawah berupa endapan vulkanik Merapi muda, sedangkan di bagian atasnya secara tidak selaras diendapkan aluvium dan koluvium (Gambar 1). Sedangkan tatanan stratigrafi berdasarkan penelitian terdahulu ditunjukkan pada Gambar 2.

Sutanto (2000) melakukan penelitian batuan vulkanik Pegunungan Kulon Progo dengan pendekatan geokronologi dan geokimia. Hasil penanggalan radiometrik KAr menunjukkan bahwa proses vulkanisme di daerah ini aktif pada Kala Oligosen Akhir sampai Miosen Tengah (29-22 Ma), dengan komposisi produk batuannya yang bervariasi dari basalt, andesit dan dasit, tetapi sebagian besar berkomposisi andesit. 
Pembentukan gunungapi yang sudah diawali sejak Oligosen Akhir merupakan respon atas penunjaman kerak Samudera Hindia. Akmaluddin (2005 dalam Didit, 2006) melakukan penanggalan radiometrik $\mathrm{K}-\mathrm{Ar}$ di Pegunungan Menoreh (Pegunungan Kulon Progo bagian utara) dan menghasilkan umur $12.434 \pm 0.749 \mathrm{Ma}$ (daerah Gunung Gandul) dan $17 \pm 2 \mathrm{Ma}$ (daerah lereng Selatan Pegunungan Menoreh). Sedangkan intrusi
Fenomena ini menunjukkan bahwa kubah Kulon Progo mengalami tektonik dan reaktivasi struktur (sesar) beberapa kali. Bukti ini diperkuat dengan hasil analisis citra Landsat oleh keberadaan kelurusankelurusan yang saling berpotongan dari formasi-formasi batuan Tersier sampai endapan Kuarter.

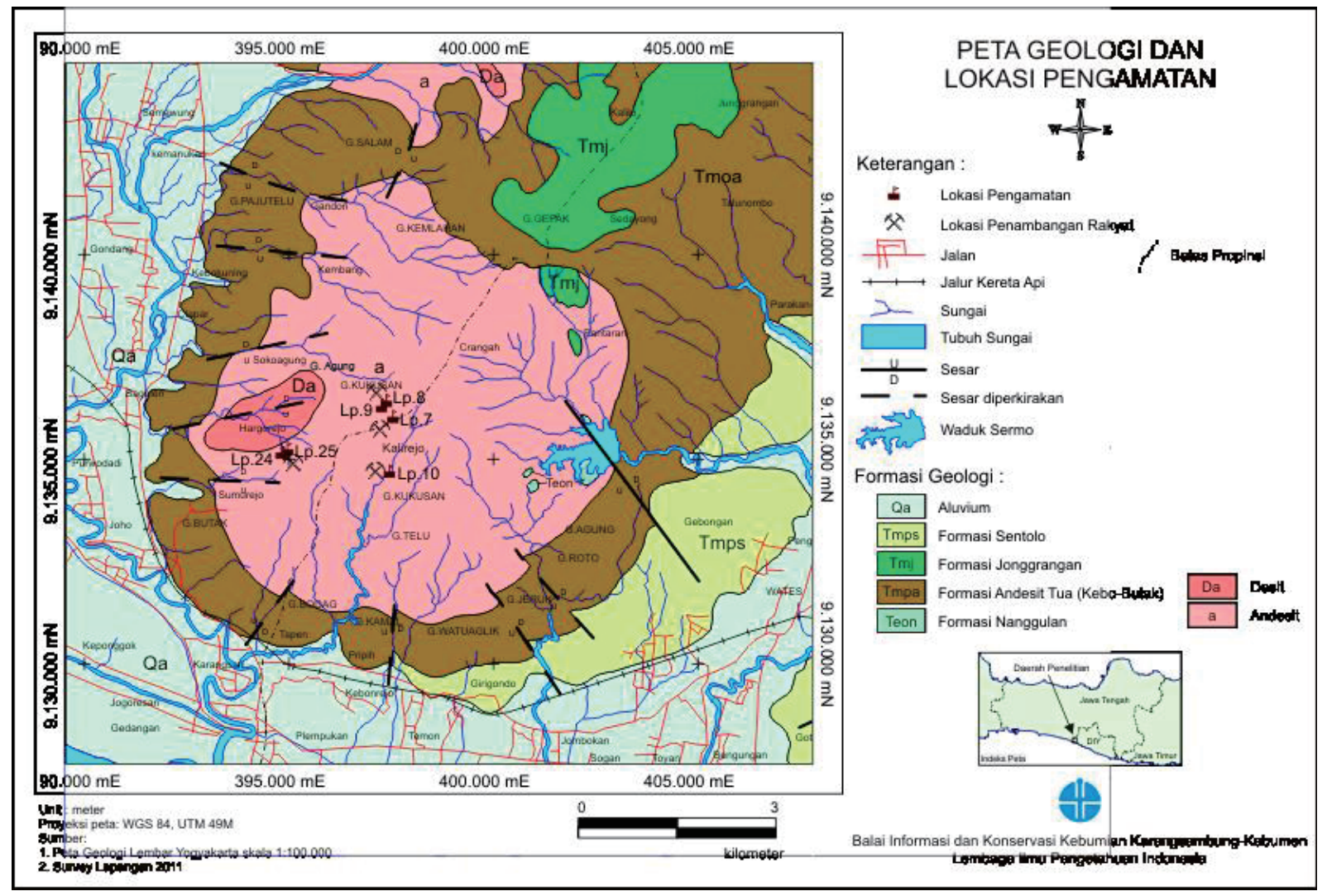

Gambar 1. Peta Geologi dan lokasi pengamatan di Kubah Kulonprogo, digambar ulang berdasarkan peta geologi lembar Yogyakarta (Raharjo dkk, 1977)

Dasit Curug menurut Harjanto A (2008) berumur 8,10 - 1,19 juta tahun yang lalu (Miosen Akhir - Kuarter). Dasit Curug tersingkap memanjang di sekitar Sekuning, Curug, Karangtalun dan Sijagu yang mengintrusi tubuh intrusi Andesit Gunung Agung.

Budiadi (2008) menyimpulkan bahwa pola Pegunungan Kulon Progo yang berarah Baratdaya- Timurlaut menyimpang dari arah umum Pegunungan Serayu Selatan yang berarah Barat-Timur. Penyimpangan ini terindikasi kuat karena pengaruh Pola Meratus yang berarah Baratdaya-Timurlaut dan Pola Jawa berarah Barat-Timur yang melewati daerah ini.

\section{HASIL DAN ANALISIS}

\section{Pengamatan Lapangan}

Pengamatan lapangan telah dilakukan pada 27 lokasi pengamatan, dimana setidaknya terdapat 6 lokasi pengamatan (LP-7, LP-8, LP 9, LP-10, LP24, LP-25) di sekitar lereng Gunung Agung dijumpai gejala alterasi dan mineralisasi, lihat Gambar 1.

\section{Lokasi LP-7 (Kalirejo, Kokap, Kulon Progo)}

Alterasi dan mineralisasi di lokasi ini berkembang pada batuan induk andesit, berwarna abu-abu gelap, tekstur porfiritik, 
tersusun oleh fenokris plagioklas, hornblenda, dan kuarsa berukuran halus. Intensitas alterasi sedang - kuat, dicirikan oleh kehadiran mineral sulfida pirit yang menyebar secara tidak merata. Silika berasosiasi dengan barit berstruktur lattice (kristalin, berbentuk pipih-tipis dan saling memotong) dan mineral lempung (Gambar 3-a dan 3-b). Pada beberapa bagian, silika bertekstur vuggy, manganis dan oksida besi di bagian permukaan, membentuk zona alterasi sekitar $50 \mathrm{~cm}$, terpotong oleh veinlet kuarsa dan berasosiasi dengan zona ubahan mineral lempung. Mineralisasi pada batuan samping berasosiasi dengan mineral sulfida (pirit) yang menyebar tidak merata dan mineral klorit dalam jumlah kecil.

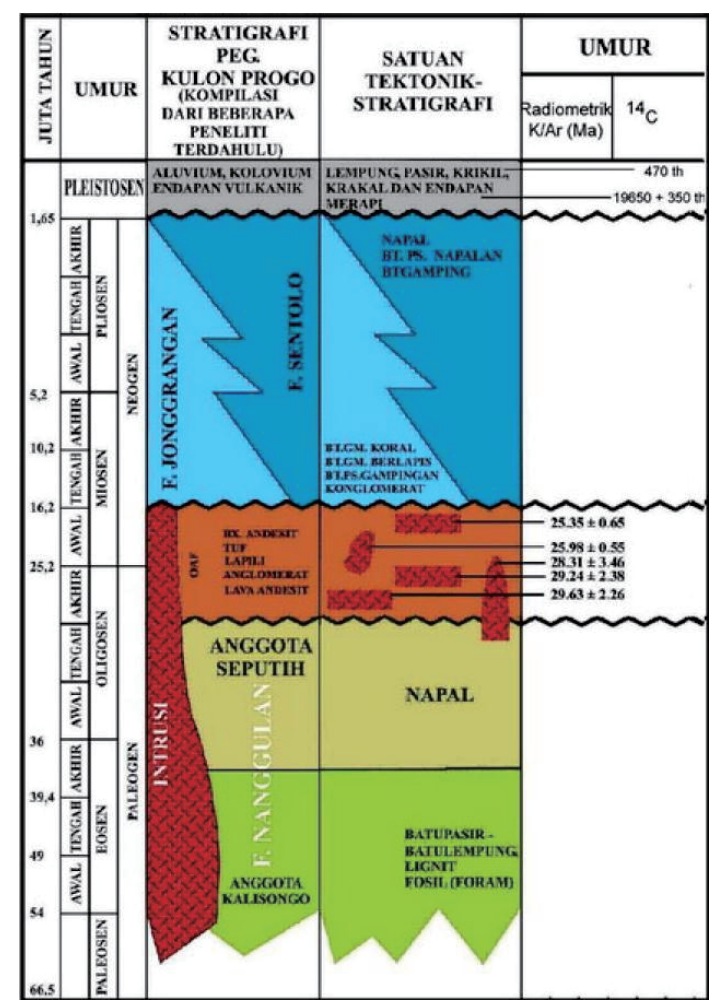

Gambar 2. Tatanan stratigrafi daerah Kulonprogo berdasarkan kompilasi penelitian terdahulu (Budiadi, 2008).

\section{Lokasi LP-8 (Hargorejo, Bagelen, Purworejo)}

Lubang penambangan emas rakyat yang dibuat secara vertikal (shaff), pada bagian permukaan dibuat vertikal 2 meter ke bawah dengan berukuran diameter lebih kurang $50 \mathrm{~cm} \times 50 \mathrm{~cm}$, dan selanjutnya dibuat lubang horizontal lebih kurang panjang 20 meter. Pada lubang bekas penambangan dijumpai urat kuarsa berwarna putih ke abu-abuan, arah urat $\mathrm{N}$ 2120 E, struktur bladed (Gambar 4-a dan 4b).

\section{Lokasi LP-10 (Plampang, Kalirejo, Kokap, Kulonprogo)}

Di lokasi ini alterasi dan mineralisasi yang berkembang berintensitas sedang kuat, berupa zona alterasi silisifikasi dicirikan oleh kehadiran mineral silika yang intensif berasosiasi dengan zona urat kuarsa-silika dan mineral lempung. Alterasi dan mineralisasi di lokasi ini berkembang pada batuan induk andesit.
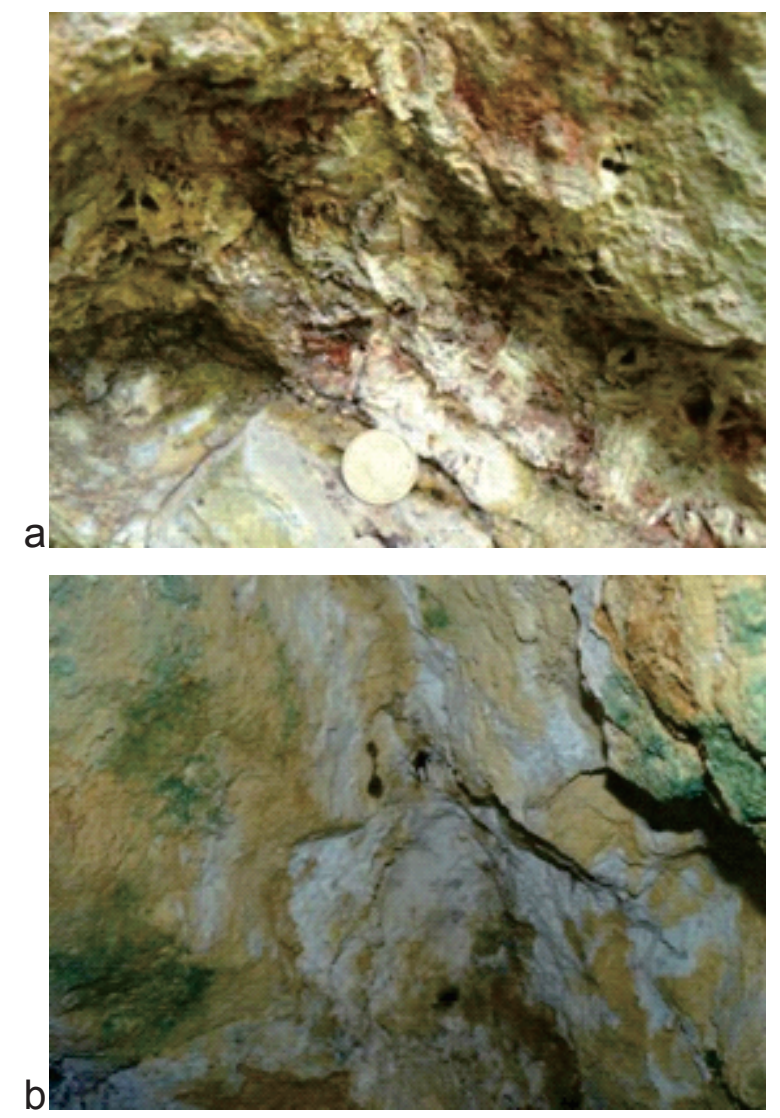

Gambar 3. a). Zona alterasi silisifikasi berasosiasi dengan barit berstruktur lattice dengan veinlet kuarsa berarah $\mathrm{N} 100^{\circ} \mathrm{E} / 65$,

b). Lempung pada zona alterasi

Pola kekar yang berkembang di lokasi pengamatan umumnya berupa kekar gerus berarah utama N $285^{\circ} \mathrm{E} / 85, \mathrm{~N} 240$ ${ }^{\circ} \mathrm{E} / 69, \mathrm{~N} 85^{\circ} \mathrm{E} / 65, \mathrm{~N} 40{ }^{\circ} \mathrm{E} / 76$. Sedangkan urat kuarsa umumnya berarah $\mathrm{N} 230^{\circ} \mathrm{E}$ pada urat ini dimanfaatkan sebagai lubang kerja sekaligus lubang produksi penambangan emas rakyat. (Gambar 5-a dan 5-b). 


\section{MAKALAH ILMIAH}
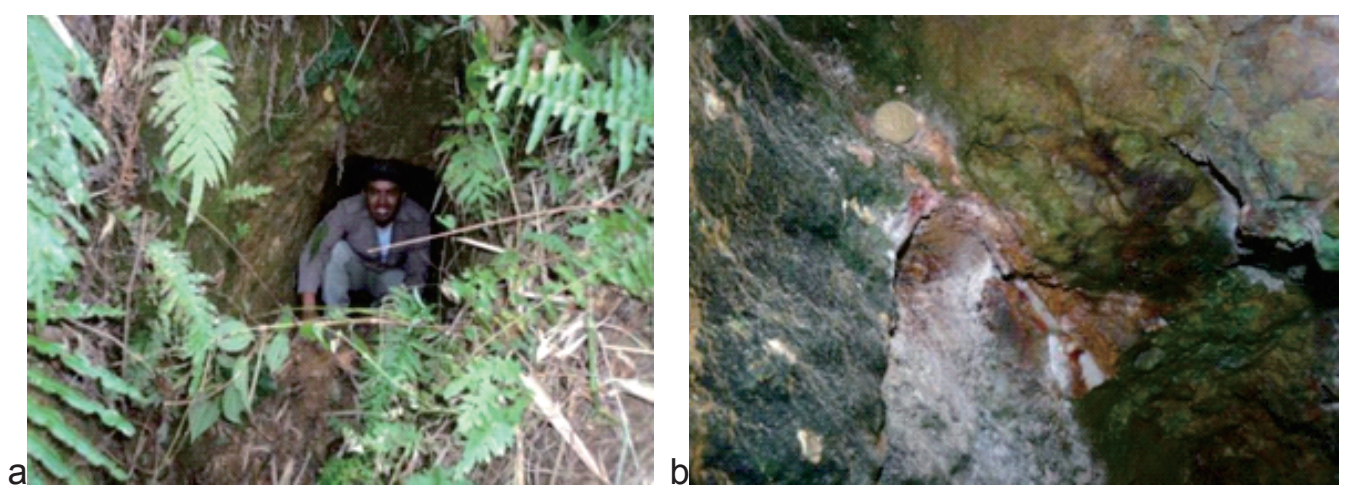

Gambar 4. Lubang bekas penambangan emas rakyat (4-a) serta urat kuarsa (4-b).
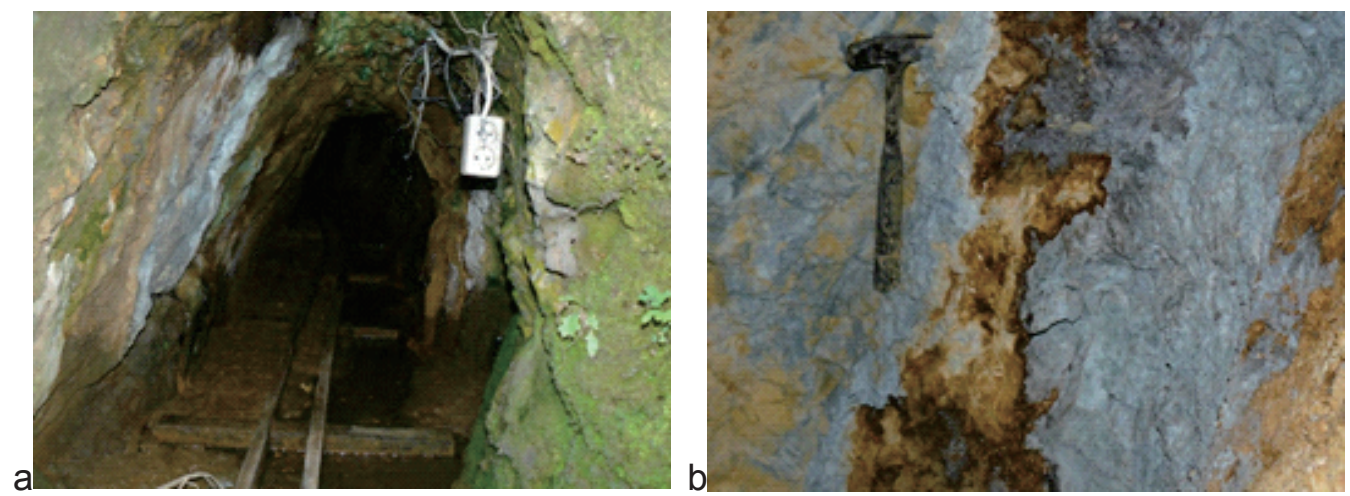

Gambar 5. a).Lubang penambangan emas rakyat berdiameter $80 \mathrm{~cm}$ dengan panjang 20 meter, b). Zona alterasi silisifikasi berasosiasi dengan ubahan mineral lempung.

\section{Lokasi LP-24 (Desa Sumorejo, Bagelen, Purworejo)}

Di lokasi ini terdapat aktivitas penambangan emas rakyat pada bagian atas bukit. Penambangan mengikuti arah urat kuarsa yang berarah barat daya-timur laut, ketebalan urat sekitar $40 \mathrm{~cm}$ dan membentuk struktur vuggy (Gambar 6-a). Pada lokasi ini alterasi berupa silisifikasi disertai pembentukan lempung argilik dengan mineralissi barit dan sulfida (Gambar 6-b).

\section{Lokasi LP-25 (Sumorejo, Bagelen, Purworejo)}

Lubang penambangan berada pada zona alterasi silisifikasi berasosiasi dengan mineral lempung. Mineral sulfida yang menyebar tidak merata berasosiasi dan zona oksida besi berwarna kemerahan yang mengisi rekahan. Pada berapa bagian tampak struktur breksiasi dengan fragmen batuan induk berupa batuan beku andesit yang mulai terubah dengan intensitas sedang - kuat. Zona urat kuarsa yang berkembang secara umum berarah $\mathrm{N} 220^{\circ} \mathrm{E} / 80$ (Gambar 7-a dan 7-b).

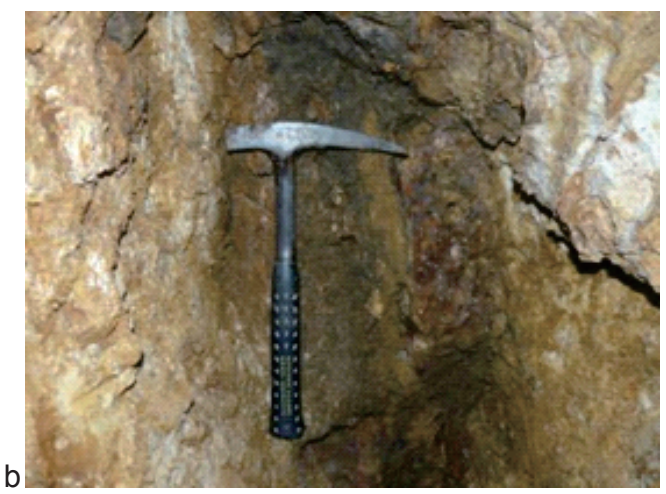

Gambar 6. Vuggy silika setebal $40 \mathrm{~cm}$ (a) dan alterasi argilik disekitarnya (b). 


\section{MAKALAH ILMIAH}
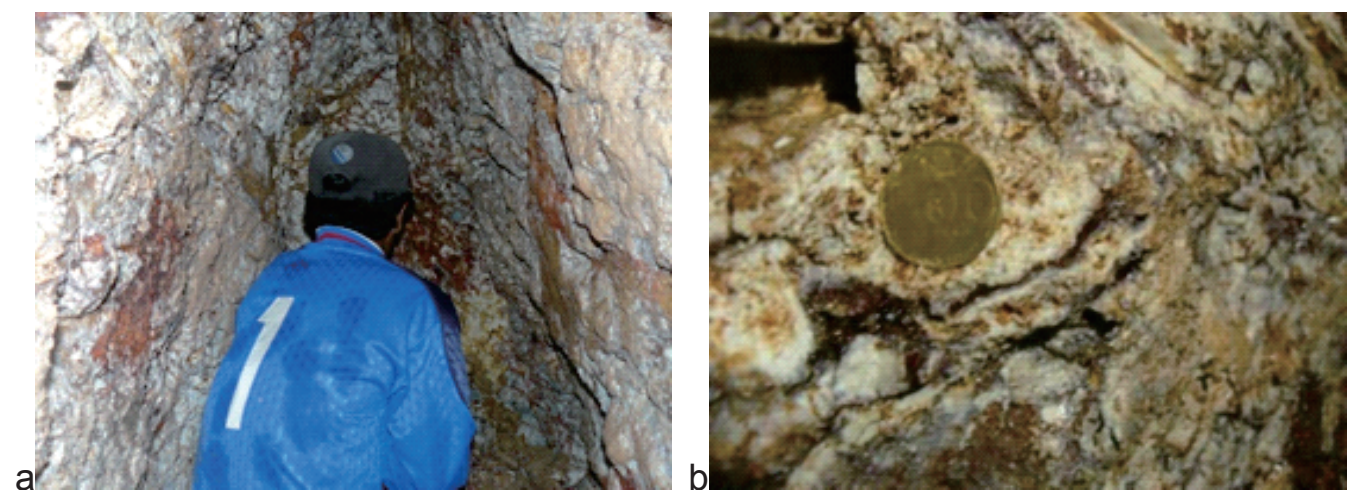

Gambar 7. a). Zona urat kuarsa berarah $N 220^{\circ} \mathrm{E} / 80$ dengan intensitas alterasi kuat, serta Zona oksida besi mengisi rekahan b). Struktur crustiform-colloform dan sulfida yang berkembang pada silika

\section{Analisis Petrografi}

Analisis petrografi dilakukan pada sayatan tipis batuan/mineral menggunakan mikroskop polarisasi Nikon yang dilengkapi dengan kamera foto analog. Secara megaskopik batuan beku pada lokasi LP-10, teralterasi dengan intensitas sedang - kuat, berwarna coklat hingga abu-abu, berasosiasi dengan zona alterasi silisifikasiargilik, dicirikan oleh kehadiran mineral silika dan mineral lempung yang intensif. Pada beberapa bagian, batuan induk terpotong

berasosiasi dengan zona alterasi silisifikasi dengan intensitas lemah-sedang, manganis setempat, oksida besi pada bagian permukaan. Di dalam sayatan tipis (Gambar 8-b) berwarna putih, nikol bersilang berwarna abu-abu, terpotong oleh alur-alur agregat kalsedonik kriptokristalin yang membentuk pola memanjang 1-2 $\mathrm{mm}$, gelapan bergelombang (60\%), disekitarnya dijumai serisit berwarna abu-abu gelap, subhedral, berukuran $0.1 \mathrm{~mm}-0.2 \mathrm{~mm}$, tidak merata $(40 \%)$.
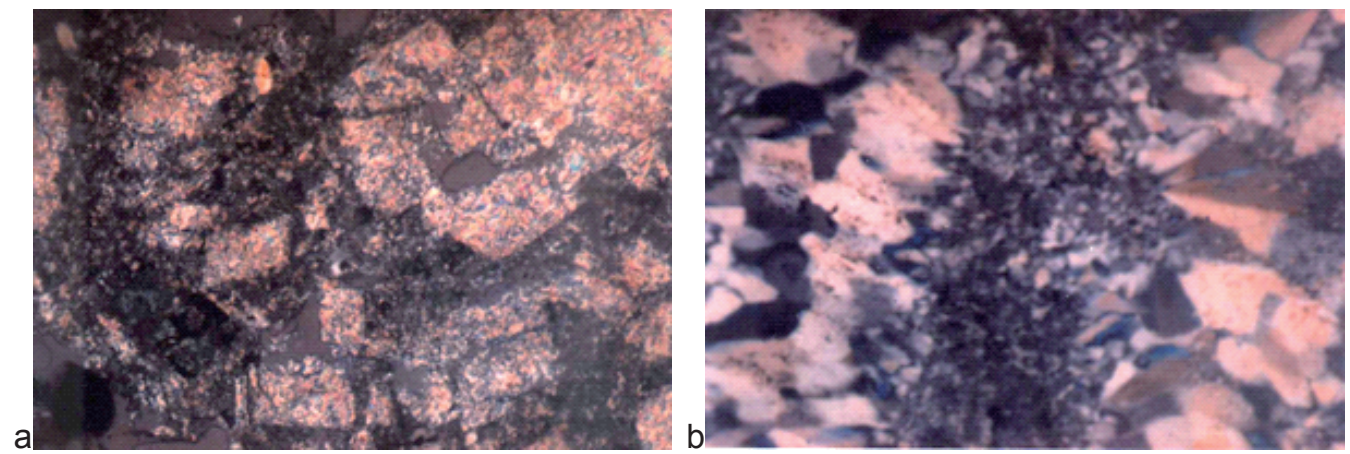

Gambar 8. a). Plagioklas pada andesit lokasi LP-10 yang terubah menjadi serisit,

b). Urat kuarsa pada lokasi LP-9 yang tersusun oleh agregat kalsedon serta serisit.

oleh zona urat kuarsa-silika. Di bawah mikroskop batuan mempunyai tekstur hipokristalin, ukuran kristal tidak seragam (in-equigranular), euhedral - subhedral. Fenokris plagioklas $(75 \%)$ hampir keseluruhan terubah menjadi serisit $(45 \%)$. Terdapat mineral opaq/oksida besi dalam jumlah kecil (5\%). Fenokris terdapat pada massa berukuran halus kriptokristalin (20 $\%$ ), foto mikroskop dapat dilihat pada Gambar 8-a.

Sedangkan urat silika-kuarsa pada lokasi LP-9 berwarna putih susu, dengan tebal 10-15 cm, berarah $\mathrm{N} 350{ }^{\circ} \mathrm{E} / 85$, memanjang 2 meter ke arah vertikal

\section{Analisis Difraksi Sinar-X (XRD)}

Analisis XRD menggunakan alat RINT2000 wide angle geniometer, difraksi sinar X menggunakan Cu Ka $/ 40$ kV/26 mA, dengan bentangan scan 2-65, yang dilakukan di Laboratorium Fisika Mineral Puslit Teknologi Mineral dan Batubara Bandung. Analisis XRD dilakukan pada lempung di zone alterasi pada lokasi LP-7 dan LP-10, sedangkan pola difraksi sinar $X$ terlihat pada gambar 9 .

Pola XRD mineral lempung pada lokasi LP-7 dan LP10 mempunyai kesamaan yang menandakan adanya kesamaan komposisi. Berdasarkan pola tersebut, kandungan 
mineralnya meliputi :

- Silicon oxide (Kuarsa)

- Iron sulfide (Pirit)

- Potassium aluminium silicate hydroxide (muskovit)
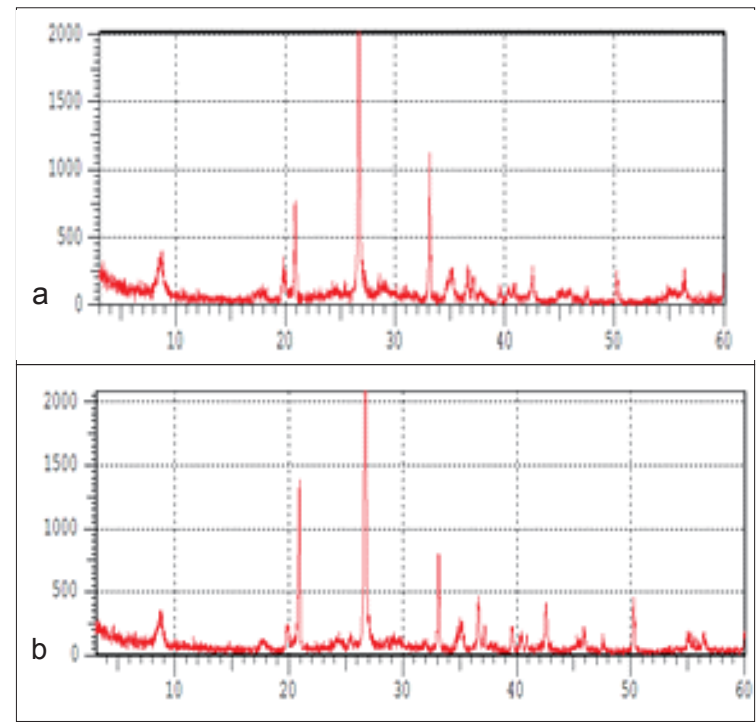

Gambar 9. Pola XRD lempung pada zone alterasi lokasi LP-7 (a) dan LP-10 (b)

\section{Analisis Kimia Mineral}

Analisis kimia mineral dilakukan dengan menggunakan metode AAS di Laboratorium Pengujian Kimia-Fisika Mineral, Pusat Sumber Daya Geologi Bandung, hasil analisis dapat dilihat pada Tabel 1. Berdasarkan hasil analisis tersebut terlihat kadar Au tertinggi $2.068 \mathrm{ppb}$ dan tidak semua urat silika mengandung $\mathrm{Au}$ tinggi, kadar terendah 50 ppb terdapat pada urat silika LP-10. Kadar Au rendah terdapat pada batuan ataupun silika dengan \% kandungan $\mathrm{Al}_{2} \mathrm{O}_{3}$ dan $\mathrm{K}_{2} \mathrm{O}$ relatif tinggi. $\mathrm{Au}$ rendah juga mempunyai korelasi dengan rendahnya $\mathrm{Ag}$ dan $\mathrm{Pb}$.

\section{Analisis Inklusi Fluida}

Analisis inklusi fluida dilakukan pada 3 (tiga) buah sampel mineral barit dan kuarsa yang dijumpai disekitar urat silika pada lokasi LP-7 (Gunung Bolong, Plampang Satu), LP9 (Hargorejo) dan LP-24 (Sumorejo).

\section{Urat kuarsa berasosiasi dengan barit, lokasi LP-7 \\ Sampel disusun oleh kristal - kristal} kuarsa berasosiasi dengan barit, mengisi celah dalam batuan sedimen klastik breksian. Kristal kuarsa berwarna keruh hingga bening berukuran relatif halus, umumnya kalsedonik. Kristal barit berwarna keruh milky dengan beberapa bagian bening. Pada kristal kuarsa dan barit sering dijumpai detritus mineral berukuran halus.

Inklusi fluida hanya dijumpai pada kristal barit, umumnya bertipe fasa tunggal kaya air (tidak mengandung gelembung udara), berbentuk anhedral - subhedral memanjang, sebagian necking, tersebar secara acak tidak terorientasi (Gambar 10).

Tabel 1. Hasil analisis kimia batuan di daerah penelitian

\begin{tabular}{|c|c|c|c|c|c|c|c|c|c|c|c|c|c|c|c|c|}
\hline No & Conto & Batuan & $\begin{array}{c}\mathrm{SiO}_{2} \\
\%\end{array}$ & $\begin{array}{c}\mathrm{Al}_{2} \mathrm{O}_{3} \\
\%\end{array}$ & $\begin{array}{c}\mathrm{Fe}_{2} \mathrm{O}_{3} \\
\%\end{array}$ & $\begin{array}{c}\mathrm{CaO} \\
\%\end{array}$ & $\begin{array}{c}\text { Mg O } \\
\%\end{array}$ & $\begin{array}{c}\mathrm{Na}_{2} \mathrm{O} \\
\%\end{array}$ & $\begin{array}{c}\mathrm{K}_{2} \mathrm{O} \\
\%\end{array}$ & $\begin{array}{c}\text { MnO } \\
\%\end{array}$ & $\begin{array}{c}\mathrm{H}_{2} \mathrm{O} \\
\%\end{array}$ & $\begin{array}{c}\mathrm{Cu} \\
\mathrm{ppm}\end{array}$ & $\begin{array}{c}\mathrm{Pb} \\
\mathrm{ppm}\end{array}$ & $\begin{array}{c}\mathrm{Zn} \\
\mathrm{ppm}\end{array}$ & $\begin{array}{c}\mathrm{Au} \\
\mathrm{ppb}\end{array}$ & $\begin{array}{c}\mathrm{Ag} \\
\mathrm{ppm}\end{array}$ \\
\hline 1 & LP 7 & $\begin{array}{l}\text { Zone } \\
\text { altrasi } \\
\text { argilik }\end{array}$ & 66,97 & 5,75 & 3,25 & 0,05 & 0,09 & 0,03 & 0,96 & 0,01 & 0,34 & 12 & 97 & 26 & 1.183 & 5 \\
\hline 2 & LP 8 & $\begin{array}{l}\text { Vein } \\
\text { silika }\end{array}$ & 65,01 & 12,86 & 12,13 & 0,14 & 0,67 & 0,24 & 3,25 & 0,02 & 1,66 & 31 & 68 & 39 & 212 & 5 \\
\hline 3 & LP 10 & $\begin{array}{l}\text { Andesit } \\
\text { terubah }\end{array}$ & 56,50 & 15,27 & 5,43 & 7,46 & 2,14 & 0,15 & 3,12 & 0,16 & 0,28 & 73 & 74 & 67 & 50 & 3 \\
\hline 4 & LP 25 & $\begin{array}{l}\text { Vein } \\
\text { silika }\end{array}$ & 84,49 & 5,48 & 3,48 & 0,07 & 0,13 & 0,10 & 1,27 & 0,01 & 0,07 & 204 & 326 & 41 & 2.608 & 23 \\
\hline 5 & LP 24 & $\begin{array}{l}\text { Vein } \\
\text { silika }\end{array}$ & 59,10 & 7,18 & 14,80 & 0,09 & 0,14 & 0,03 & 0,77 & 0,02 & 0,12 & 3245 & 1870 & 294 & 1.318 & 39 \\
\hline
\end{tabular}




\section{MAKALAH ILMIAH}

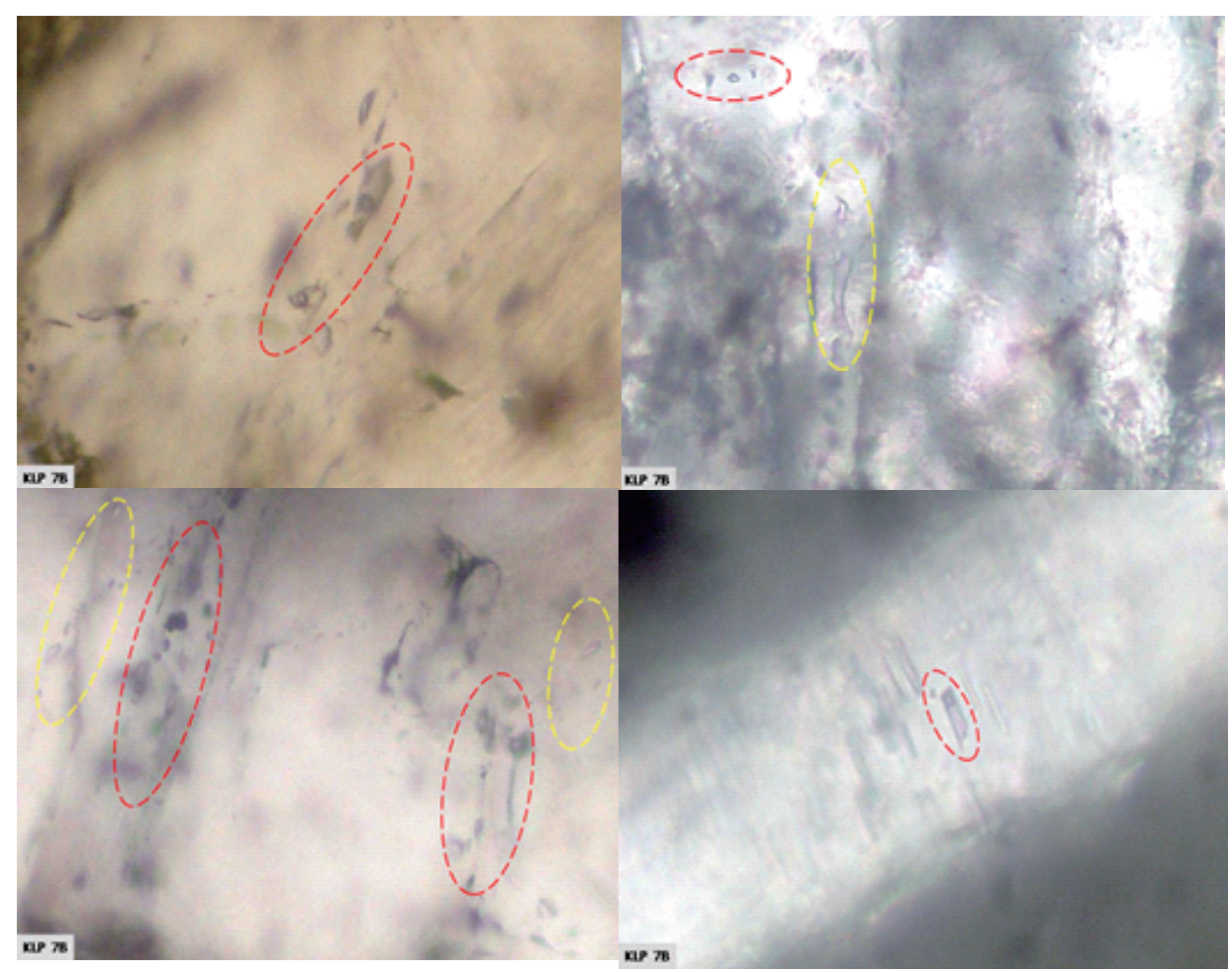

Gambar 10. Foto mikroskop barit lokasi LP- 7, inklusi fasa ganda (lingkaran merah), inklusi fasa tunggal kaya air (lingkaran kuning).

Pada inklusi fluida fase ganda mineral barit dilakukan pengukuran mikrotermometri, dimana hasilnya dapat dilihat pada Tabel 2 .

Tabel 2.

Hasil pengukuran mikrotermometri inklusi fase ganda pada Barit

\begin{tabular}{|l|c|}
\hline No Conto & LP 7 \\
\hline Host kristal & Barit \\
\hline $\operatorname{Tm}\left({ }^{\circ} \mathrm{C}\right)$ & $-2,1 \sim-1,8$ \\
\hline $\operatorname{Th}\left({ }^{\circ} \mathrm{C}\right)$ & $175 \sim 202$ \\
\hline Mode $\mathrm{Th}\left({ }^{\circ} \mathrm{C}\right)$ & 185 \\
\hline$\% \mathrm{WT} \mathrm{NaCl}$ & $3,3 \sim 3,9$ \\
\hline Kedalaman $(\mathrm{m})$ & $84,4 \sim 163,6$ \\
\hline Tekanan (bar) & $8,8 \sim 15,9$ \\
\hline
\end{tabular}

\section{PEMBAHASAN}

Alterasi dan mineralisasi yang berkembang di daerah penelitian mempunyai intensitas lemah hingga sedang. Alterasi lemah diindikasikan oleh munculnya mineral sulfida serta ubahan mineral lain dalam jumlah sedikit $(<25 \%)$. Sedangkan alterasi menengah diindikasikan oleh munculnya zona alterasi silisifikasi hingga argilik yang diikuti oleh mineralisasi logam mulia, logam dasar dan sulfida, dengan volume mineral sekunder berkisar $25-75 \%$. Zona alterasi dengan intensitas menengah muncul pada lokasi LP 7, 8, 9, 10 di sekitar Plampang, Kokap serta lokasi LP 24 dan 25 di Desa Sumorejo, Bagelen.

Alterasi silisifikasi ditandai dengan munculnya urat dan stockwork silika-kuarsa yang diikuti oleh mineralisasi logam mulia (Au), barit dan sulfida serta lempung argilik di sekitarnya. Pembentukan urat silika-kuarsa yang diikuti mineralisasi Au umumnya mempunyai arah Timur Laut - Barat Daya dengan arah antara $\mathrm{N} 212{ }^{\circ} \mathrm{E}$ hingga $\mathrm{N} 230$ ${ }^{\circ} \mathrm{E}$. Zona alterasi dan mineralisasi juga terdapat di sekitar intrusi dasit Gunung Curug. Berdasarkan hasil pengamatan lapangan, analisis petrografi, analisis XRD, analisis kimia mineral dan inklusi fluida maka dapat disusun tabel asosiasi mineral pada zone alterasi (tabel 3) serta stabilitas mineral pada berbagai suhu pembentukan (tabel 4). 
Tabel 3.

Asosiasi mineral yang terbentuk pada zona alterasi

\begin{tabular}{|c|c|c|c|c|c|c|c|}
\hline \multirow[t]{2}{*}{ Lokasi } & \multirow[t]{2}{*}{ Batuan Asal } & \multirow[t]{2}{*}{ ALTERASI } & \multicolumn{3}{|c|}{ MINERALISASI } & \multirow{2}{*}{$\begin{array}{l}\text { Analisis } \\
\text { Kimia Mineral }\end{array}$} & \multirow{2}{*}{$\begin{array}{l}\text { Analisis Inklus } \\
\text { fluida }\end{array}$} \\
\hline & & & Lapangan & XRD lempung & \begin{tabular}{|l|} 
Analisis \\
Petrografi
\end{tabular} & & \\
\hline LP-7 & Andesit OAF & $\begin{array}{l}\text { Silisifikasi, } \\
\text { argilik }\end{array}$ & $\begin{array}{l}\text { - Lattice barit } \\
\text { - Pirit, manganis } \\
\text { - Urat silika, vuggy } \\
\text { (N } 100^{\circ} \mathrm{E} / 65 \text { ) } \\
\text { - Lempung }\end{array}$ & $\begin{array}{l}\text { - Kuarsa } \\
\text { - Pirit } \\
\text { - Muscovite }\end{array}$ & $\begin{array}{l}\text { - Sericite } \\
\text { (ubahan } \\
\text { plagioklas) }\end{array}$ & - Au:1183 ppb & $\begin{array}{l}\text { - Th: } 175-202^{\circ} \mathrm{C} \\
\text { - h: } 80-160 \mathrm{~m}\end{array}$ \\
\hline LP-8 & Andesit OAF & $\begin{array}{l}\text { Silisifikasi, } \\
\text { argilik }\end{array}$ & $\begin{array}{l}\text { - Urat silika N } 212 \\
{ }^{\circ} \mathrm{E} / 73 \\
\text { - Lempung argilik }\end{array}$ & $\begin{array}{l}\text { - Kuarsa } \\
\text { - Muscovite }\end{array}$ & $\begin{array}{l}\text { - Sericite } \\
\text { (ubahan } \\
\text { plagioklas) }\end{array}$ & - Au: $212 \mathrm{ppb}$ & - \\
\hline LP-9 & Andesit OAF & $\begin{array}{l}\text { Silisifikasi, } \\
\text { argilik }\end{array}$ & $\begin{array}{l}\text { - Urat silika (N } 350 \\
{ }^{\circ} \mathrm{E} / 85 \text { ) } \\
\text { - Lempung argilik }\end{array}$ & - & $\begin{array}{l}\text { - Sericite } \\
\text { (ubahan } \\
\text { plagioklas }\end{array}$ & - & $\begin{array}{l}\text { - Th: } 157-180^{\circ} \mathrm{C} \\
\text { - h : } 50-100 \mathrm{~m}\end{array}$ \\
\hline LP-10 & Andesit OAF & $\begin{array}{l}\text { Silisifikasi, } \\
\text { argilik }\end{array}$ & $\begin{array}{l}\text { - Urat silika (N } 230 \\
{ }^{\circ} \mathrm{E} \text { ) } \\
\text { - pirit } \\
\text { - Lempung argilik }\end{array}$ & $\begin{array}{l}\text { - Kuarsa } \\
\text { - Pirit } \\
\text { - Muscovite }\end{array}$ & $\begin{array}{l}\text { - Plagioklas } \\
\text { terubah kuat } \\
\text { menjadi } \\
\text { sericite }\end{array}$ & - Au: 50 ppb & - \\
\hline LP-24 & Andesit OAF & Silisifikasi & $\begin{array}{ll}\text { - } & \text { barit } \\
\text { - } & \text { pirit } \\
\text { - Urat silika, vuggy } \\
\left.\text { (N170 }{ }^{\circ} \mathrm{E}\right)\end{array}$ & - Kuarsa & - & - Au:1318 ppb & $\begin{array}{l}\text { - Th: } 185-225^{\circ} \mathrm{C} \\
\text { - h : } 80-290 \mathrm{~m}\end{array}$ \\
\hline LP-25 & Andesit OAF & $\begin{array}{l}\text { Silisifikasi, } \\
\text { argilik }\end{array}$ & $\begin{array}{l}\text { - Urat silika (N } 220 \\
{ }^{\circ} \mathrm{E} / 80 \text { ) } \\
\text { - Pirit } \\
\text { - Lempung }\end{array}$ & $\begin{array}{l}\text { - Kuarsa } \\
\text { - Muscovite }\end{array}$ & - & - Au:2608 ppb & - \\
\hline
\end{tabular}

Tabel 4.

Stabilitas mineral pada berbagai suhu pembentukan (Morisson, 1977)

\begin{tabular}{|l|l|l|l|l|l|l|l|l|l|l|l|l|l|l|l|l|l|}
\hline Mineral & 0 & 900 & \\
Host: \\
Andesit \\
OAF
\end{tabular}

Berdasarkan data lapangan, dijumpai adanya mineral barit yang berasosiasi dengan silika-kuarsa. Barit merupakan mineral dengan stabilitas suhu antara $40-250^{\circ} \mathrm{C}$, namun dengan dijumpainya struktur bladed, maka indikasi pembentukan mineral terjadi pada suhu dibawah boiling level $\left(<230^{\circ} \mathrm{C}\right)$. Data XRD lempung hasil alterasi disekitar urat kuarsa dijumpai adanya muskovit, kuarsa dan pirit yang mengindikasikan bahwa proses alterasi pembentukan lempung terjadi pada suhu tinggi antara $280-340^{\circ} \mathrm{C}$ (Morisson, 1977). Hal ini diperkuat dengan data petrografi dengan dijumpainya serisit dalam jumlah banyak sebagai hasil ubahan mineral plagioklas pada batuan andesit teralterasi.

Sedangkan berdasarkan data mikrotermometri inklusi fluida maka dapat dibuat histogram suhu peleburan dan homogenisasi (Gambar 11). Suhu peleburan berkisar $-2,1 \mathrm{~s} / \mathrm{d}-1,8^{\circ} \mathrm{C}$ dimana modenya pada $-2^{\circ} \mathrm{C}$. Suhu homogenisasi berkisar antara $175-200^{\circ} \mathrm{C}$ dengan mode pada suhu $185^{\circ} \mathrm{C}$. Kandungan $\mathrm{NaCl}: 3,3-3,9 \%$ berat, Inklusi umumnya berfasa tunggal, namun terdapat juga beberapa inklusi fasa ganda yang dapat diukur suhu miktotermometrinya. Inklusi umumnya juga sudah mengalami necking yang menandakan adanya proses tektonik sehingga cenderung akan merusak inklusi yang ada. Pengukuran mikrotermometri memberikan kisaran suhu homogenisasi antara $175^{\circ} \mathrm{C}$ hingga $202^{\circ} \mathrm{C}$, suhu ini masih di bawah suhu pembentukan mika/serisit namun masuk di dalam suhu stabilitas mineral barit. Berdasarkan data kandungan $\mathrm{NaCl}$ dan suhu homogenisasi maka dapat ditentukan posisi pembentukan mineral menggunakan kurva Hass (1971). Posisi pembentukan mineral diperkirakan terjadi pada kedalaman $80-160 \mathrm{~m}$ di bawah permukaan tanah (Gambar 12). 


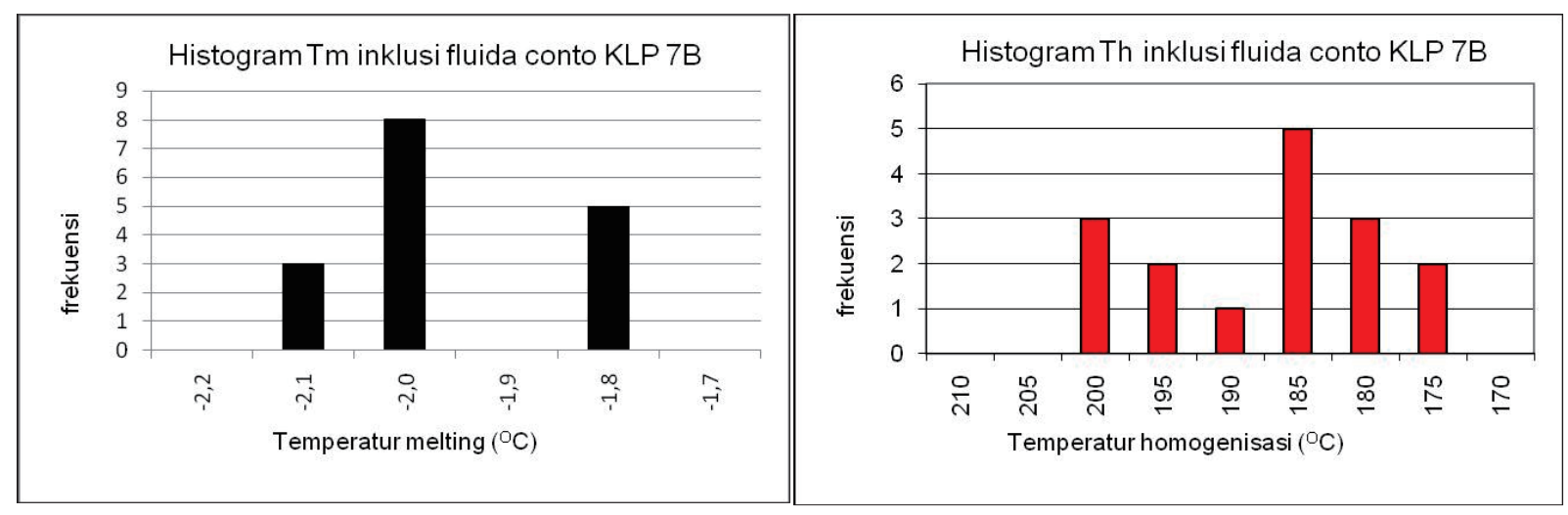

Gambar 11.Histogram Tm dan Th sampel LP 7B, Tm didominasi suhu $-2,0^{\circ} \mathrm{C}$, Th memperlihat satu mode pada suhu $185^{\circ} \mathrm{C}$.

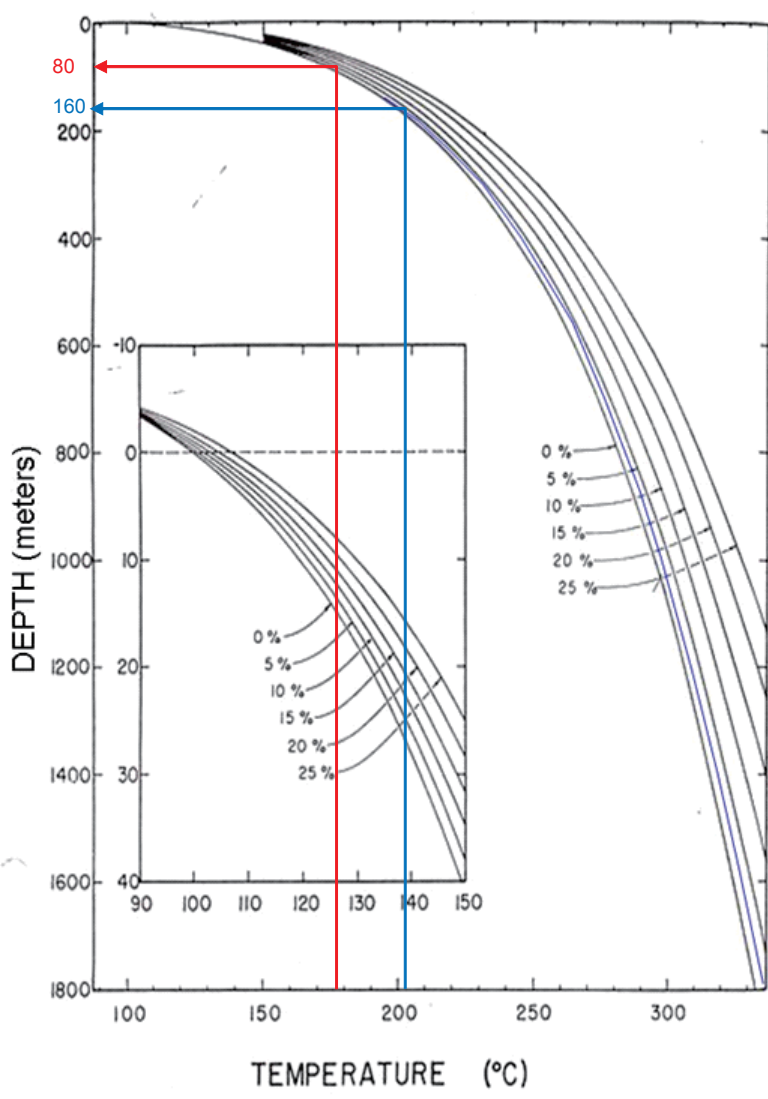

Gambar 12. Hasil pengeplotan suhu homogenisasi LP-7.B, pada kurva Hass 1971

Berdasarkan data asosiasi mineral yang didapat di lapangan, data analisis petrografi, data analisis XRD, dan data inklusi fluida, maka proses alterasi diperkirakan terjadi dalam 2 tahap. Pada tahap pertama terjadi alterasi hidrotermal pada suhu tinggi antara $280-340^{\circ} \mathrm{C}$ sehingga mengubah mineral felspar menjadi serisit serta pembentukan mineral sulfida, logam dasar dan logam mulia. Terbentuknya mineral serisit dalam jumlah signifikan menandakan bahwa larutan hidrotermal bersifat netral pada sulfida rendah, hal ini juga diikuti oleh pembentukan struktur banded ataupun colloform-crustiform pada urat kuarsa. Pada tahap kedua, terjadi sirkulasi air tanah yang bercampur dengan larutan hidrotermal sehingga suhunya turun dan terjadi proses alterasi pada suhu yang lebih rendah di sekitar boiling level pada suhu $175-202^{\circ} \mathrm{C}$. Proses alterasi pada tahap dua ini akan menghasilkan pembentukan mineral barit, sulfida dan logam mulia. Alterasi pada tahap kedua diperkirakan terjadi pada kondisi sulfida rendah sehingga memunculkan asosiasi mineral barit, pirit dan kuarsa. Barit merupakan mineral yang terbentuk pada kondisi basa sulfida rendah. Menurut Hedenquist J. W., dan White N. C., (1995) mineralisasi yang terbentuk pada sulfida tinggi terjadi pada kondisi asam yang dicirikan dengan mineralisasi alunit, kaolinit, pirofillit, diaspor. Sedangkan mineralisasi pada sulfida rendah terjadi pada kondisi netral disertai mineralisasi illite-sericite dan illit-smectite dengan struktur crustiformcolloform. Alterasi tahap pertama diperkirakan terjadi pada kedalaman lebih dari $500 \mathrm{~m}$, sedangkan tahap kedua pada kedalaman $100-160 \mathrm{~m}$. Model konseptual mineralisasinya dapat dilihat pada Gambar 13. Gunung Agung serta beberapa gunung lainnya merupakan intrusi andesit yang terjadi pada kala Oligosen Akhir - Miosen Tengah sekitar 29.67 - 22.35 juta tahun lalu. Andesit menerobos Formasi Andesit Tua dan Formasi Nanggulan yang diperkirakan terjadi pada beberapa tahap. Sedangkan intrusi Dasit Gunung Curug berumur 8,1 juta 


\section{MAKALAH ILMIAH}

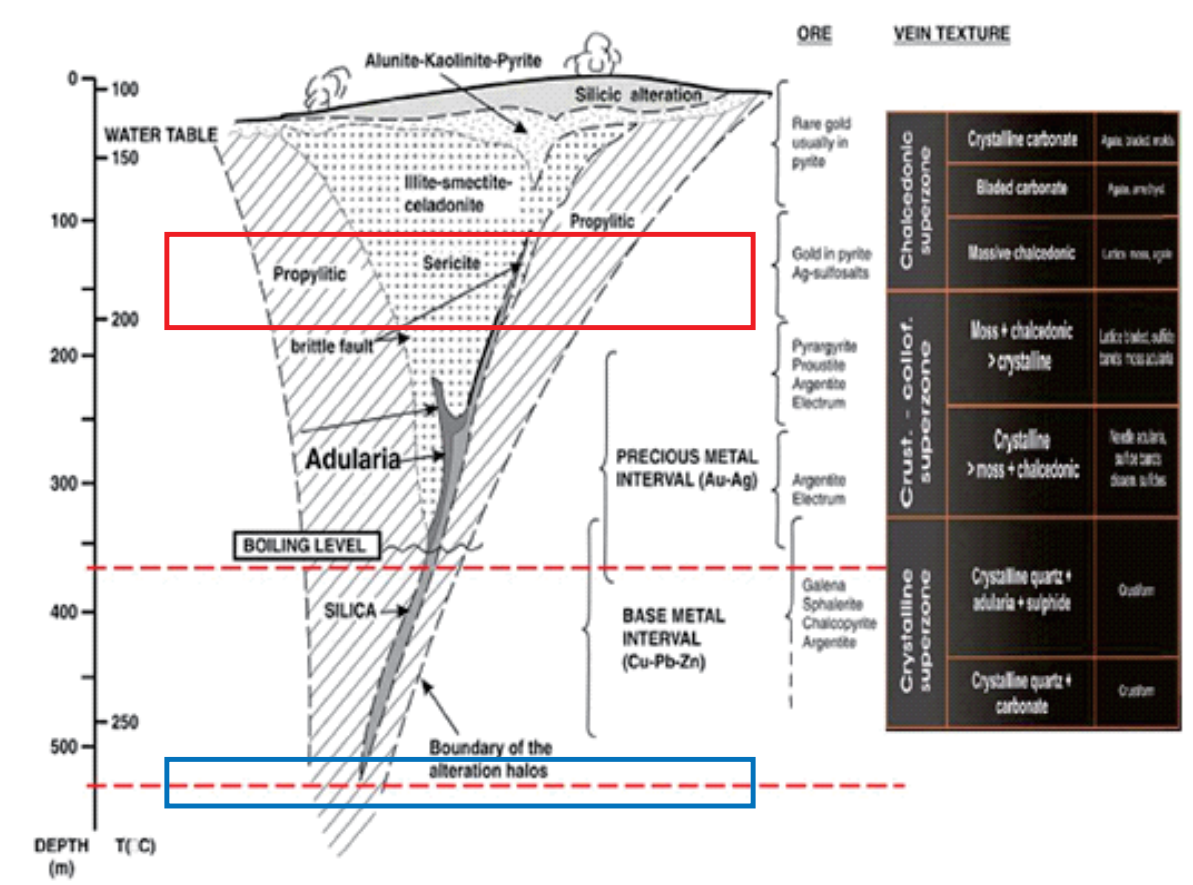

Gambar 13. Model konseptual pembentukan urat kuarsa dan barit di daerah penelitian (Buchanan, 1981)

tahun lalu mengintrusi Andesit Gunung Agung. Terjadinya dua kali proses intrusi ini diperkirakan berpengaruh kuat terhadap proses mineralisasi yang lebih intensif di sekitar Gunung Agung, hal ini juga ditandai dengan meningkatnya kadar Au disekitar LP24 dan LP-25 yang berada disekitar intrusi dasit.

\section{KESIMPULAN}

Alterasi yang berkembang di sekitar Gunung Agung adalah silisifikasi danargilik dengan tingkat ubahan lemah. Mineralisasi emas berkadar rendah (50 - $2608 \mathrm{ppb})$, dengan asosiasi mineral barit dan sulfide. Diperkirakan terbentuk dalam dua pada suhu $40-250^{\circ} \mathrm{C}$ dan $280^{\circ} \mathrm{C}-340^{\circ} \mathrm{C}$, bertipe mineralisasi sulfida rendah.

\section{UCAPAN TERIMAKASIH}

Ucapan terimakasih disampaikan kepada semua pihak yang telah banyak membantu hingga terlaksananya semua penyelidikan dengan lancar.

\section{DAFTAR PUSTAKA}

Asikin S., Handoyo, A., Pratistho, B., Gafoer, S., 1992, Geologi Lembar Banyumas, skala 1 : 100,000. Puslitbang Geologi, Bandung

Bemmelen, R.W., 1949. Geology of Indonesia. vol. IA, Martinus Nijhoff, the Hague, pp. 637-647.

Buchanan, L.J., 1981. Precious metal deposits associated with volcanic environments in the Southwest Arizona. Geological Society Digest, 14, p.237-262.

Budiadi E, 2008. Peranan Tektonik Dalam Mengontrol Geomorfologi Daerah Pegunungan Kulon Progo, Disertasi Doktor Ilmu Geologi, UNPAD, Bandung, Tidak dipublikasikan

Hedenquist J. W., White N. C., 1995, Ephitermal Gold Deposit : Style, Characteristics and Implication, Society of Economic Geologists, Newsleter no 23, p.1, 9-13.

Harjanto, A., 2008; Magmatisme dan Mineralisasi di Daerah Kulonprogo; Disertasi Doktor Teknik Geologi, ITB, Bandung, tidak dipublikasikan.

Soeria Atmaja R., Maury R.C., Bellon H., Pringgoprawiro H., Polve M., and Priadi B., 1994, "The Tertiary Magmatic Belt in Java" Journal of South EastAsian Earth Sciences, Vol 9, No 1/2, p 13-27

Sutanto 2000. Batuan Vulkanik Daerah Kulon Progo, geokronologi dan geokimia, Buletin Tekmira Nomor 14

Rahardjo, W., Sukandarrumidi, \& Rosidi, H.M.S. 1995. Peta Geologi Lembar Yogyakarta skala 1 : 100,000. Puslitbang Geologi, Bandung 


\section{MAKALAH ILMIAH}

Morrison, 1977, Important Hydrotermal Minerals and Their Significance, 7 ed, Kingston Morisson Ltd, New Zealand

Haas, J. L., Jr., 1971. The effect of salinity on the maximum thermal gradient of a hydrothermal system at hydrostatic pressure. Economic Geology 66, pp. 940-946. 